\title{
Dangerous Liaisons: Money and Citizenship
}

\author{
Ayelet Shachar
}

Vogue predictions that citizenship is diminishing in relevance or perhaps even vanishing outright, popular among jetsetters who already possess full membership status in affluent democracies, have failed to reach many applicants still knocking on the doors of well-off polities. One can excuse the world's destitute, those who are willing to risk their lives in search of the promised lands of migration in Europe or America, for not yet having heard the prophecies about citizenship's decline. But the same is not true for the well-heeled who are increasingly active in the market for citizenship: the ultra-rich from the rest of the world. They are willing to dish out hundreds of thousands of dollars to gain a freshly-minted passport in their new 'home country.' That this demand exists is not fully surprising given that this is a world of regulated mobility and unequal opportunity, and a world where not all passports are treated equally at border crossings. Rapid processes of market expansionism have now reached what for many is the most sacrosanct non-market good: membership in a political community. More puzzling is the willingness of governments - our public trustees and legal guardians of citizenship - to engage in processes that come very close to, and in some cases cannot be described as anything but, the sale and barter of membership goods in exchange for a hefty bank wire transfer or large stack of cash.

Everybody knows that immigration is among the most contentious policy issues of our times, and recent years have witnessed a 'restrictive turn'1 with respect to ordinary immigration and naturalisation applicants, such as those who enter on the basis of a family reunification claim or for humanitarian reasons. The situation is different, however, for the world's moneyed elite, who can sidestep many of the standard requirements for settlement by 'buying' their way into the political community. The public act of naturalisation - of turning a non-member into a citizen - has always borne an air of legal magic, with the result that it is the "most densely regulated and

1 Joppke, C. (2007), 'Beyond National Models: Civic Integration Policies for Immigrants in Western Europe', West European Politics 30 (1): 1-22; Orgad, L. (2010), 'Illiberal Liberalism: Cultural Reflections on Migration and Access to Citizenship in Europe', American Journal of Comparative Law 58: 53-106.

R. Bauböck (ed.), Debating Transformations of National Citizenship,

IMISCOE Research Series,

https://doi.org/10.1007/978-3-319-92719-0_2 
most politicized aspect of citizenship laws' ${ }^{2}$. At stake is the regulation of the most important and sensitive decision that any political community faces: how to define who belongs, or ought to belong, within its circle of members. Not everyone knows, however, that governments are now proactively facilitating faster and smoother access to citizenship for those who can pay. Revealing insights about the current state of citizenship can be gained, I will argue in this short essay, by examining who is given this red-carpet treatment, and on what basis.

Consider the following examples. Affluent foreign investors were offered citizenship in Cyprus as 'compensation' for their Cypriot bank account deposit losses. In 2012, Portugal introduced a 'golden residence permit' to attract real estate and other investments by well-to-do individuals seeking a foothold in the EU. Spain recently adopted a similar plan. On 12 November 2013, Malta approved amendments to its Citizenship Act that put in place a new individual investor legal category that will allow high-net-worth applicants to gain a 'golden passport' in return for $€ 650,000$; this sum was later increased to 1.15 million, opening a gilded backdoor to European citizenship. Under these cash-for-passport programmes, many of the requirements that ordinarily apply to those seeking naturalisation, such as language competency, extended residency periods or renunciation of another citizenship, are waived as part of an active competition, if not an outright bidding war, to attract the ultra-rich. Portugal, for example, offers a fast track for qualified applicants that entitles them to a 5 year permanent residence permit, visa-free travel in Schengen countries, the right to bring in their immediate family members, and ultimately the right to acquire Portuguese citizenship and with it the benefits of EU citizenship. This package comes with a hefty price tag: a capital transfer investment of $€ 1$ million, a real estate property purchase at a value of $€ 500,000$, or the creation of local jobs. The investment needs to remain active in Portugal for the programme's duration. Alas, the individual who gains the golden permit bears no similar obligation. Simply spending 7 days in Portugal during the first year and fourteen days in the subsequent years is enough to fulfil the programme's requirements. So much for the conclusion of the International Court of Justice in the 1955 Nottebohm decision that 'real and effective ties' between the individual and the state are expected to undergird the grant of citizenship.

2 Bauböck, R. \& S. Wallace Goodman (2010), 'Naturalisation', EUDO Citizenship Policy Brief No. 2, available at http://cadmus.eui.eu/handle/1814/51625, p. 1. 
In Malta, recipients of the golden passport will be vetted in accordance with a discretionary ministerial act that puts in place little transparency and accountability. Government officials have made clear that applicants can expect an expedited treatment, meaning that they will not have to 'stand in the queue' like everyone else. In addition, the names of golden passport recipients would remain confidential, making it close to impossible ever to know to whom the polity has sold a precious part of its soul. This last provision has raised the ire of the opposition. Their concern is that concealing the identity of those who gain membership by literally purchasing citizenship makes it so that 'Maltese [a]re now being denied the right to know who is Maltese' ${ }^{3}$. The secrecy provision was eventually withdrawn in the eleventh hour, but the basic structure of the programme remains intact: privileged and fast-track naturalisation, allowing 'any Tom, Dick and Harry ... [to] buy a Maltese passport without ever setting foot on Maltese soil.' A recent survey ${ }^{4}$ shows that the vast majority of the population opposes the sale of citizenship in principle, and rejects this scheme in particular, detached as it is from any residence or other requirements that would establish ties with the passportgranting country and society.

Beyond Europe, those seeking a new passport can look to St. Kitts and Nevis, where economic citizenship can be purchased for as low as $\$ 250,000$ (for a lump sum) or $\$ 400,000$ (if monies are directed to a real estate project), and issued within months. They might also consider Antigua and Barbuda, which is the latest in a growing list of countries to roll out a citizenship-by-investment programme or the Commonwealth of Dominica. Whereas ordinarily the law requires significant residence periods for those seeking naturalisation in these island nations (fourteen years in St Kitts and Nevis, seven years in the Commonwealth of Dominica and in Antigua and Barbuda, respectively), the residency requirement is reduced to merely seven days - a short vacation under the tropical sun - or even waived altogether for those who purchase their fast-tracked passport.

The citizenship-by-investment programmes that I have just described fall into the category of what we might call unfettered cash-for-passport exchanges. No 'nexi' between the country and the passport recipient are

3 'Updated. Mario de Marco: "Opposition will not support prostitution of Malta’s identity, citizenship", Malta Today, 9 November 2013, available at https://www.maltatoday.com.mt/news/national/31325/opposition-proposeschange-of-name-to-individual-donor-programme-20131109\#.Ws3jxHK-nZs

4 'Contentious citizenship scheme approved', Malta Today, 12 November 2013, available at https://www.maltatoday.com.mt/news/national/31402/contentiouscitizenship-scheme-approved-20131112\#.Ws3i9XK-nZs 
required; only the investment monies must 'reside' in the country for a fixed term. This is to be distinguished from more traditional programmes, themselves the subject of perennial critique, under which migrant millionaires (to borrow David Ley's apt term) can receive an admission visa through a designated business-investment stream, but would then have to more or less comply with standard residency and naturalisation requirements ${ }^{5}$. Such programmes are found in, among other places, Australia, New Zealand, Hong Kong, the United Kingdom and the United States. Both kinds of programme raise serious ethical quandaries, but the unfettered cash-for-passport programmes are more extreme and blatant than the traditional investment programmes. They contribute to some of the most disturbing developments in $21^{\text {st }}$-century citizenship, including the emergence of new forms of inequality and stratification. Instead of retreating to the background as some theorists had forecasted, states are proactively creating and exacerbating inequalities through their selective and managed migration policies, setting up easy-pass citizenship for some while making membership more restrictive and difficult to achieve for others. This new world order reveals tectonic pressures and introduces urgent dilemmas about the proper scale, scope and relations of justice and mobility, citizenship and (selective) openness. These developments also bear a profound impact on immigration law and policy on the ground, since they entail processes through which the boundary between state and market is constantly being tested, eroded, and blurred.

It is these intricate and underexplored interactions between state and market that are at the heart of my inquiry into emerging selective migration regimes and transactional visions of citizenship ${ }^{6}$. Legally, the sovereign prerogative to issue a valid and internationally recognised passport is reserved in our international system to states alone. Governments and only governments - not markets - can secure and allocate the precious legal good of membership in the political community. But what happens when the logic of capital and markets infiltrates this classic statist expression of sovereignty? The proliferation of what I have called unfettered cash-for-passport programmes is a dramatic example of this pattern at work and it invites our

5 Dzankic, J. (2012), 'The Pros and Cons of Ius Pecuniae: Investor Citizenship in Comparative Perspective', Robert Schuman Centre for Advanced Studies, EUDO Citizenship Observatory Working Paper 2012/14, Florence: European University Institute, available at http://cadmus.eui.eu/handle/1814/21476

6 Shachar, A. (2006), 'The Global Race for Talent: Highly Skilled Migrants and Competitive Immigration Regimes', NYU Law Review 81 (2006): 148-206; Shachar, A. (forthcoming), Olympic Citizenship: Migration and the Global Race for Talent. Oxford: Oxford University Press. 
critical scrutiny, especially since governments that use these programmes often do so in the name of advancing their country's national interest while paradoxically setting up dangerous connections between money and access to citizenship, possibly to the detriment of the basic egalitarian and participatory thrust of political membership as we currently know it. These developments raise core ethical and legal questions. Why are states putting citizenship up for sale? And what precisely is wrong with easy-pass naturalisation along the lines of the cash-for-passport programmes? Is it the queue jumping? The attaching of a price tag to citizenship? The erosion of something foundational about political membership itself? Or, perhaps, all of the above?

Surely, zealous free-marketeers will enthusiastically defend such programmes as freeing us from the shackles of culture, nation and tradition and moving citizenship forward to a new and more competitive global age of transactional contracting in which, as Nobel Prize laureate Gary Becker once put it, a price mechanism substitutes for the complicated criteria that now determine legal entry ${ }^{7}$. As much as Becker would like to deny it, though, these programmes have something of a 'whiff of scandal' not only due to frequent accusations of money laundering and fraud ${ }^{8}$, but also because of something deeper and more profound. Citizenship as we know it (at least since Aristotle) is comprised of political relations; as such, it is expected to both reflect and generate a notion of participation, co-governance, and a degree of solidarity among those included within the body politic. It is difficult to imagine how these values could be preserved under circumstances in which insiders and outsiders are distinguished merely by the ability to pay a certain price. The objection here is to the notion that everything, including political membership, is 'commensurable' and reducible to a dollar value. This is what makes cash-for-passport exchanges, even if they account for only a limited stream or quota of entrants per year, deeply problematic and objectionable. The sale and barter of citizenship, even if initially reserved only for a small stream of recipients, nevertheless sends a loud and unmistakable message in both law and social ethics about whom the contemporary market-friendly state gives priority to in the immigration and naturalisation line and whom it covets most as a future citizen. This expressive conduct and the new grammar of market-infused valuation it entails tell us something

\footnotetext{
Becker, G. (1992), 'An Open Door for Immigrants - the Auction', Wall Street Journal, October 14 1992, A1.

8 'Selling Citizenship: Papers Please', The Economist, September 28 2013, available at https://www.economist.com/news/ international/21586843-hard-up-countries-flog-passports-papers-please.
} 
important about the volatile state of citizenship today and the direction in which we may be heading.

Although economists will be quick to note that cash-for-passport programmes can create a hefty stream of revenue for governments, this is a hardly a strong enough justification to endorse them. The desire to enlarge their coffers may, as a matter of real-life experience, explain why some countries offer these programmes. From a normative perspective, however, such an exchange threatens to corrupt the good that is put on sale: what changes when we 'sell' citizenship is not just the price tag of membership, but its substantive content as well. As it plays a more and more important role in countries' immigration and naturalisation policies and priorities, citizenship-for-sale may also gradually reshape the greater class of those who are likely to enjoy political membership. Reliance on a price mechanism alone, to the exclusion of other important considerations, would not only prevent the vast majority of the world's population from ever gaining a chance to access citizenship in well-off polities. Taken to its logical conclusion (as reductio) it might also lead, corrosively and over time, to a world where anyone included in the pool of members must pay up, or risk 'falling helplessly to the wayside" ${ }^{9}$.

Several scholars have taken up the task of imagining how our world might look were the market -rather than the state - to govern access to, and the acquisition of, political membership. As one study explains, '[i]f we take the basic incidents of citizenship to be protection of members and participation in modes of governance, the market for citizenship could form around offer of and demand for these services. Indeed, the offer of broader packages of citizenship services would be the basis for product differentiation'10. 'Product differentiation,' it should be noted, is a euphemism for providing lesser rights and services in exchange for lower fees ${ }^{11}$. Farewell, then, to the hard-earned ideal of inclusive citizenship as equal membership. In its absence, auction mechanisms and supply-and-demand rules may well replace our (however imperfect) procedures of exerting some degree of democratic governance and collective decision-making on what it means to belong to a political community, how to obtain a secure legal status of citizenship, and on what conditions.

9 Spiro, P. J. (2008), Beyond Citizenship: American Identity After Globalization. Oxford: Oxford University Press, 134.

10 Downes, D. M. \& R. Janda (1998), 'Virtual Citizenship', Canadian Journal of Law and Society 13 (2): 27-61, at 55.

11 Jordan, B. \& F. Düvell (2003), Migration: The Boundaries of Equality and Justice. Cambridge: Polity Press. 
Even staunch defenders of the market approach to citizenship understand that they are facing a hard sell. Becker, for one, admits that "people object to the sale of permits because, as they say, "citizenship is not to be for sale""12, and this is a moral intuition that runs deep. As evidenced by recent debates over the instalment of cash-for-passport programmes, most people have strong reservations against attaching a price tag to citizenship ${ }^{13}$. The reasons are many. As already mentioned, such a move may cause irreparable harm to the vision of citizenship as grounded in long-term relations of trust and shared responsibility and may prefigure the conflation of the political and ethical with the economic and calculative. It may also undermine membership bonds grounded in co-authorship, cross-subsidisation of risk, and even sacrifice that might be expected in times of need. What is more, citizenship currently involves making collective decisions, and translating those decisions into binding commitments, in the context of a political project that is far larger than oneself, and that extends well beyond the lifespan of each generation of members - a time horizon that will be extremely hard to sustain under a regime of strategic transactions, according to which 'wealth buys membership.' Turning citizenship into a money-based prize also contradicts any notion of complex equality through blocked exchange according to which advantage in one sphere (here, wealth) cannot be legitimately transferred to another (in this case, membership) ${ }^{14}$. This makes the idea of selling membership unnerving for anyone who objects to the ultimate triumph of economics over politics, the reduction of our public life and ethics into mere pecuniary transactions, or the imperialistic idea that 'trades' occupy the full terrain of human value and meaning ${ }^{15}$.

Another set of concerns arises in the context of supranational citizenship, as in the derivative structure of European citizenship. The actions of those member states that take the liberty to put their national citizenship 'on sale' indirectly affects the supranational political membership good that is shared by other countries, which may resist such commodification. There are also complex questions about to whom (beyond its own citizenry) the transacting

\section{Above n. 7.}

13 Borna, S. \& J. M. Stearns (2002), 'The Ethics and Efficacy of Selling National Citizenship', Journal of Business Ethics 37 (2): 193-207, at 197.

14 Walzer, M. (1983), Spheres of Justice: A Defense of Pluralism and Equality. New York: Basic Books.

15 Radin, M. J. (1987), 'Market-Inalienability', Harvard Law Review 100: 1849-1937; Sunstein, C. R. (1997), 'Incommensurability and Kinds of Valuation: Some Applications in Law', in R. Chang (ed.), Incommensurability, Incomparability, and Practical Reason, 234-254. Cambridge, MA: Harvard University Press; Sandel, M. J. (2013), What Money Can't Buy: The Moral Limits of Markets. New York: Farrar, Straus and Giroux. 
government is obliged to provide justificatory reasons concerning its selective admission and naturalisation policies. Need it justify itself to other member states? To the Commission of the European Union? To would-be entrants who might have had a shot at admission through standard migration streams (family, employment, and humanitarian) but who are priced out of the advantage given to those who can afford a 'golden passport'? From a global perspective, cash-for-passport programmes clearly exacerbate pre-existing inequalities rather than alleviate them. Should the sedentary populations of the migrant millionaires' countries of origin, which are typically less stable or poorer than the destination countries, get to weigh in as well? Or, if an expansive allaffected-interests principle is applied, perhaps anyone at all who may be unfairly and arbitrarily affected should have a voice in these decisions ${ }^{16}$. And what about migrants who are already settled in the country but ineligible to benefit from naturalisation schemes that require no knowledge or familiarity with the political structures, main civic institutions, history or language of the country, and who are subject instead to ever more demanding civic integration requirements? If civic integration is a required precondition to the bestowment of full membership by the state (as restrictive citizenship tests increasingly indicate), how can this demand only apply to some and not to others?

After all, there is no rational connection between delivering a stack of cash or sending in a bank wire transfer and establishing the kind of participation and equal standing among fellow citizens that the political bonds of membership are meant to represent and foster. From this vantage point, the transaction in citizenship, even if carefully regulated and implemented by monopolistic governments or their authorised delegates, should be prohibited. Taken to its dystopian extreme, this approach may lead to a situation whereby the size of their wallets, and nothing else, distinguishes suitable from unsuitable candidates for initial entry and eventual citizenship. This kind of transaction, as lawyers and philosophers like to put it, is valuedegrading: the trading in citizenship 'taints,' 'degrades' or outrightly 'corrupts' (in the moral sense) its value as a good. We might in the same vein say that these cash-for-citizenship programmes detrimentally affect the "character of the goods themselves and the norms that should govern them' ${ }^{17}$. As critics of commodification have been at pains to clarify in other contexts ${ }^{18}$,

16 Goodin, R. (2007), 'Enfranchising All Affected Interests, and Its Alternatives', Philosophy and Public Affairs 35 (1): 40-68.

17 Sandel, M. J. (2013), What Money Can't Buy: The Moral Limits of Markets. New York: Farrar, Straus and Giroux, 113.

18 Cohen, I. G. (2003), 'The Price of Everything, the Value of Nothing: Reframing the Commodification Debate', Harvard Law Review 117 (689): 689-710. 
it is not that $€ 1$ million is too high or too low a price, but that placing a 'for sale' tag on citizenship, no matter what amount is written on it, has a corrosive effect on non-market relations, eroding the ties that bind and altering our view of what it means to belong to a political community. Just as we should be critical of granting citizenship according to nothing but the fortuitous and arbitrary circumstances of station of birth ${ }^{19}$, I believe we must resist, with even greater force, the notion that money can buy 'love of country' - or secure membership in it.

If governments and activists are listening, they should heed the warning signs. The ideal of equal citizenship has been inflicted with many wounds over the past decades, and has always been more of an aspiration than a reality. However, the dangerous and increasingly frequent links between money and access to political membership reflected in the more calculated, mercantilist-like perceptions of citizenship that have given rise to unfettered cash-for-passport programmes threaten not only the implementation of the ideal, but the ideal itself. Courting the world's moneyed elite by relaxing standard admission and naturalisation requirements may enrich the coffers of a country in the short run, but in the long haul it risks cheapening something far more important: citizenship itself.

Open Access This chapter is licensed under the terms of the Creative Commons Attribution 4.0 International License (http://creativecommons.org/licenses/by/4.0/), which permits use, sharing, adaptation, distribution and reproduction in any medium or format, as long as you give appropriate credit to the original author(s) and the source, provide a link to the Creative Commons license and indicate if changes were made.

The images or other third party material in this chapter are included in the chapter's Creative Commons license, unless indicated otherwise in a credit line to the material. If material is not included in the chapter's Creative Commons license and your intended use is not permitted by statutory regulation or exceeds the permitted use, you will need to obtain permission directly from the copyright holder.

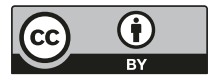

19 Shachar, A. (2009), The Birthright Lottery: Citizenship and Global Inequality. Cambridge, MA: Harvard University Press; Shachar, A. (2011), 'Earned Citizenship: Property Lessons for Immigration Reform', Yale Journal of Law \& the Humanities 23: 110-158. 